ISSN 0122-5383

\title{
DETERMINATION OF WELL-DRAINAGE AREA FOR POWER-LAW FLUIDS BY TRANSIENT PRESSURE ANALYSIS
}

\author{
DETERMINACIÓN DEL ÁREA DE DRENAJE DE UN POZO PARA \\ FLUIDOS LEY DE POTENCIA MEDIANTE ANÁLISIS DE PRESIONES
}

Freddy-Humberto Escobar*1, Laura-Jimena Vega ${ }^{1}$ and Luis-Fernando Bonilla ${ }^{1}$

1Universidad Surcolombiana, Neiva, Huila, Colombia

e-mail: fescobar@usco.edu.co

(Received Apr. 09, 2012; Accepted Sep. 11, 2012)

\section{ABSTRACT}

ince conventional oil is almost depleted, oil companies are focusing their efforts on exploiting heavy oil reserves. A modern and practical technique using the pressure and pressure derivative, log-log plot for estimating the well-drainage area in closed and constant-pressure reservoirs, drained by a vertical well is presented by considering a non-Newtonian flow model for describing the fluid behavior. Several synthetic examples were presented for demonstration and verification purposes.

Such fluids as heavy oil, fracturing fluids, some fluids used for Enhanced Oil Recovery (EOR) and drilling muds can behave as either Power-law or Bingham, usually referred to as the non-Newtonian fluids. Currently, there is no way to estimate the well-drainage area from conventional well test analysis when a non-Newtonian fluid is dealt with; therefore, none of the commercial well test interpretation package can estimate this parameter (drainage area).

Keywords: Non-Newtonian, Power-Law, Pressure analysis, Well drainage area, Well test.

How to cite: Escobar, F. H., Vega, L. J. \& Bonilla, L. F. (2012). Determination of well-drainage area for power-law fluids by transient pressure analysis. CT\&F - Ciencia, Tecnología y Futuro, 5(1), 45-56.

${ }^{*}$ To whom correspondence should be addressed 


\section{RESUMEN}

P

vesto que el crudo convencional está en proceso de agotamiento, las compañías petroleras están enfocando sus esfuerzos en desarrollar las reservas de crudo pesado. En este artículo se presenta una metodología práctica y moderna para estimar el área de drenaje de un pozo vertical, considerando modelos de fluido no-Newtoniano y usando un gráfico logarítmico de presión y derivada de presión, aplicado a sistemas cerrados o abiertos.

Fluidos tales como crudos pesados, fluidos de fracturamiento, fluidos para recobro mejorado y lodos de perforación se comportan ya sea como fluidos ley de potencia o Bingham, y son más conocidos como fluidos no-Newtonianos. Actualmente, no existe forma de estimar el área de drenaje de un pozo, si un fluido no-Newtoniano requiere ser considerado y por lo tanto, ningún paquete comercial de análisis de presiones puede estimar este parámetro (área de drenaje).

Palabras clave: No Newtoniano, Ley de potencia, Análisis de presiones, Área de drenaje del pozo, Prueba de pozo.

\section{RESUMO}

$\mathrm{P}$

sto que o cru convencional está em processo de esgotamento, as companhias petroleiras estão enfocando seus esforços em desenvolver as reservas de cru pesado. Neste artigo apresenta-se uma metodologia prática e moderna para estimar a área de drenagem de um poço, considerando modelos de fluído não-Newtoniano e usando uma gráfica logarítmica de pressão e derivada de pressão aplicada a sistemas fechados ou abertos. Realizaram-se vários exercícios sintéticos para verificar a metodologia.

Fluídos tais como crus pesados, fluídos de fraturamento, fluídos para recuperação melhorada e lodos de perfuração se comportam iá seja como fluídos lei de potência ou Bingham e são mais conhecidos como fluídos não-Newtonianos. Atualmente, não existe forma de estimar a área de drenagem de um poço, se um fluído não-Newtoniano requer ser considerado e, portanto, nenhum pacote comercial de análise de pressões pode estimar este parâmetro (área de drenagem).

Palavras chave: Não-Newtoniano, Lei de potência, Análise de pressões, Área de drenagem do poço, Priva de poço. 


\section{INTRODUCTION}

Conventional well test interpretation models do not apply to reservoirs containing non-Newtonian fluids such as some paraffinic and heavy crude oils, some completion and stimulationWW treatment fluids (polymer solutions, foams, drilling muds, etc.). NonNewtonian fluids are generally classified as time independent, time dependent and viscoelastic. Examples of the first classification are the Bingham, pseudoplastic and dilatant fluids which are commonly encountered by petroleum engineers.

Power-law fluids are also divided into two branches: pseudoplastic when the flow index behavior $(n)$ is smaller than the unity and dilatant when the flow index behavior falls between 1 and 2. Many fluids in the oil industry display a pseudoplastic behavior.

The pressure derivative of a power-law fluid differs from a Newtonian one. For a Newtonian fluid the flow index $n$ is equal to unity and the pressure derivative has a zero slope during the radial flow regime. For pseudoplastic fluids the pressure derivative during radial flow regime is a straight line with an increasing slope as the flow index behavior decreases. For dilatant fluids the situation is the opposite.

Pseudoplastic and dilatant fluids have no yield point. For pseudoplastic fluids, the slope of shear stress versus shear rate decreases progressively and tends to become constant for high values of shear stress. The simplest model is power law,

$\tau=k \gamma^{n} ; \quad n<1$

$K$ and $n$ are constants which differ for each particular fluid. $K$ measures the flow consistency and $n$ measures the deviation from the Newtonian behavior for which $k=m$ and $n=1$ in Equation 1.

Dilatants fluids are similar to pseudoplastic except that the apparent viscosity increases as the shear stress increases. The power-law model also describes the behavior of dilatant fluids but $n>1$.

For well test interpretation, several analytical and numerical models taking into account Bingham and pseudoplastic non-Newtonian behavior have been introduced in the literature for a better understanding of reservoir behavior. Most of them deal with fractured wells and homogeneous formations and well test interpretation is conducted via either the classical straightline conventional analysis or type-curve matching. Only few studies considered pressure-derivative analysis. However, there exists a need of a more practical and accurate way of characterizing such systems.

Many studies in petroleum engineering, chemical engineering and rheology have focused on nonNewtonian fluid behavior through porous formations, among them, we can name Hirasaki and Pope (1974); Ikoku (1979); Ikoku and Ramey (1979); Odeh and Yang (1979); Savins (1969) and Van-Poollen and Jargon (1969). Ikoku (1978) also presented several analytical solutions including finite systems, which are used in this paper, for non-Newtonian fluids in homogeneous and heterogeneous reservoirs. Several numerical and analytical models have been proposed to study the transient behavior of non-Newtonian fluid in porous media. Since all of them were published before the eighties, when the pressure derivative concept was inexistent; interpretation technique was conducted using either conventional analysis or type-curve matching. As pointed out by Gringarten (2008), the conventional method is poor for identification of the flow regime and has zero verification. On the other hand, type-curve matching has been limited to regular identification and verification. Pressure derivative and deconvolution are very good for both purposes.

Vongvuthipornchai and Raghavan (1987) were the first to use the pressure-derivative concept for well test analysis of non-Newtonian fluids, and later on, KatimeMeindl and Tiab (2001) presented the first extension of the TDS technique to non-Newtonian fluids. Igbokoyi and Tiab (2007) used type-curve matching for interpretation of pressure test for non-Newtonian fluids in infinite systems including skin and wellbore storage effects. Recent applications of the derivative function to non-Newtonian system solutions are presented by Escobar, Martínez and Montealegre (2010) and Martínez, Escobar and Montealegre (2011) who applied the $T D S$ technique to radial composite reservoirs with a Non-Newtonian/Newtonian interface for pseudoplastic and dilatants systems, respectively. However, all the 
above mentioned cases consider infinite reservoirs, and therefore the drainage area is never involved as it is in this paper.

\section{MATHEMATICAL DEVELOPMENT}

A partial differential equation for radial flow of nonNewtonian fluids following a power-law relationship through porous media was proposed by Ikoku (1978). Coupling the non-Newtonian Darcy's law with the continuity equation, they derived a rigorous partial differential equation:

$\frac{\partial^{2} P}{\partial r^{2}}+\frac{n}{r} \frac{\partial P}{\partial r}=c_{t} \phi n\left(\frac{\mu_{e f f}}{k}\right)^{1 / n}\left(-\frac{\partial P}{\partial r}\right)^{(n-1) / n} \frac{\partial P}{\partial t}$

This equation is nonlinear. For analytical solutions, a linearized approximation was also derived by Ikoku (1978):

$\frac{1}{r^{n}} \frac{\partial}{\partial r}\left(r^{n} \frac{\partial P}{\partial r}\right)=G r^{1-n} \frac{\partial P}{\partial t}$

Where:

$G=\frac{3792.188 n \phi c_{t} \mu_{e f f}}{k}\left(96681.605 \frac{h}{q B}\right)^{1-n}$

and,

$\mu_{\text {eff }}=\left(\frac{H}{12}\right)\left(9+\frac{3}{n}\right)^{n}\left(1.59344 \times 10^{-12} k \phi\right)^{(1-n) / 2}$

The dimensionless quantities were also introduced by Ikoku and Ramey (1979) as,
$P_{D N N}=\frac{\Delta P}{141,2(96681,605)^{1-n}\left(\frac{q B}{h}\right)^{n} \frac{\mu_{e f f} r_{w}^{1-n}}{k}}$

$t_{D N N}=\frac{t}{G r_{w}^{3-n}}$

$P_{D N}=\frac{k h \Delta P}{141.2 q \mu_{N} B}$

$t_{D N}=\frac{0.0002637 k t}{\phi \mu_{N} c_{t} r_{w}^{2}}$

$r_{D}=\frac{r}{r_{w}}$

Where the suffix $N$ indicates Newtonian and the suffix $N N$ indicates non-Newtonian. For the cases of bounded and constant-pressure reservoirs, Ikoku (1978) presented the respective solutions to Equation 3. The initial and boundary conditions for the closed outer boundary case are:

$P_{D N N}\left(r_{D}, 0\right)=0$

$\left(\frac{\partial P_{D N N}}{\partial r_{D}}\right)_{r_{D}=1}=-1$ for $t_{D N N}>0$

$\left(\frac{\partial P_{D N N}}{\partial r_{D}}\right)_{r_{e D}=1}=0$ for $t_{D N N}$

The analytical solution in the Laplace space domain for a reservoir with a no-flow (or referred as to closed) external boundary and constant-rate production at the well is given as the closed reservoirs under constantrate case is given by Ikoku (1978) as:

$$
\bar{P}(\tilde{s})=\frac{\left\{K_{2 /(3-n)}\left[\frac{2}{3-n} \sqrt{\tilde{s}} r_{e D}^{(3-n) / 2}\right] \bullet I_{\frac{1-n}{3-n}}\left[\frac{2}{3-n} \sqrt{\tilde{s}}\right]+I_{2 /(3-n)}\left[\frac{2}{3-n} \sqrt{\tilde{s}} r_{e D}^{(3-n) / 2}\right] \cdot K_{\frac{1-n}{3-n}}\left[\frac{2}{3-n} \sqrt{\tilde{s}}\right]\right\}}{\left(\tilde{s}^{3 / 2}\left\{I_{2 /(3-n)}\left[\frac{2}{3-n} \sqrt{\tilde{s}} r_{e D}^{(3-n) / 2} \cdot K_{2 /(3-n)}\left[\frac{2}{3-n} \sqrt{\tilde{s}}\right]-K_{2 /(3-n)}\left[\frac{2}{3-n} \sqrt{\tilde{s}} r_{e D}^{(3-n) / 2}\right] \bullet I_{2 /(3-n)}\left[\frac{2}{3-n} \sqrt{\tilde{s}}\right]\right\}\right)\right.}
$$


For the case of constant-pressure external (or referred to as open) external boundary, the boundary condition given by Equation 13 is changed to:

$$
P_{D N N}\left(r_{e D}, t_{D N N}\right)=0
$$

And the analytical solution for such case is given by Ikoku (1978) as:

$$
\bar{P}(\tilde{s})=\frac{\left\{I_{\frac{1-n}{3-n}}\left[\frac{2}{3-n} \sqrt{\tilde{s}} r_{e D}(3-n) / 2\right] \cdot K_{\frac{1-n}{3-n}}\left[\frac{2}{3-n} \sqrt{\tilde{s}}\right]-K_{\frac{1-n}{3-n}}\left[\frac{2}{3-n} \sqrt{\tilde{s}} r_{e D}{ }^{(3-n) / 2}\right] \cdot I_{\frac{1-n}{3-n}}\left[\frac{2}{3-n} \sqrt{\tilde{s}}\right]\right\}}{\left(\tilde{s}^{3 / 2}\left\{I_{2 /(3-n)}\left[\frac{2}{3-n} \sqrt{\tilde{s}}\right] \cdot K_{\frac{1-n}{3-n}}\left[\frac{2}{3-n} \sqrt{\tilde{s}} r_{e D}{ }^{(3-n) / 2}\right]+K_{2 /(3-n)}\left[\frac{2}{3-n} \sqrt{\tilde{s}}\right] \cdot I_{\frac{1-n}{3-n}}\left[\frac{2}{3-n} \sqrt{\tilde{s}} r_{e D}(3-n) / 2\right]\right\}\right)}
$$

The dimensionless pressure derivative during radialflow regime is governed by an expression presented by Escobar et al. (2010) as:

$$
\left(t_{D} * P_{D}^{\prime}\right)_{r N N}=0.5 t_{D N N}^{\alpha}
$$

Escobar et al. (2010) also presented more practical expressions for the determination of both permeability and skin factor:

$$
\frac{k}{\mu_{e f f}}=\left[70.6(96681.605)^{(1-\alpha)(1-n)}\left(\frac{0.0002637 t_{r}}{n \phi c_{t}}\right)^{\alpha}\left(\frac{q B}{h}\right)^{n-\alpha(n-1)}\left(\frac{1}{\left(t^{*} \Delta P^{\prime}\right)_{r}}\right)\right]^{\frac{1}{1-\alpha}}
$$

$$
s=\frac{1}{2}\left[\begin{array}{l}
{\left[\frac{0.0002637 k t_{r}}{n \phi \mu_{e f f} c_{t} r_{w}^{3-n}}\left(96681.605 \frac{h}{q B}\right)^{n-1}\right]^{\alpha}\left(\frac{\Delta P}{\left(t^{*} \Delta P\right)}\right)_{r}-} \\
\ln \left(\frac{k t_{r}}{n \phi \mu_{e f f} c_{t} r_{w}^{3-n}}\left(96681.605 \frac{h}{q B}\right)^{n-1}\right)+7.43
\end{array}\right]
$$

Where $a$ is the slope of the pressure-derivative curve and is defined by:

$\alpha=\frac{1-n}{3-n}$

Being $n$ the flow behavior index which may be found from the slope of the pressure-derivative curve during radial flow regime.
Using the solutions provided by Ikoku (1978), we present pressure and pressure derivative plots for such behaviors as shown in Figures 1 and 2. It is seen in these plots that for closed systems that the late-time pressure-derivative behaviors for both pseudoplastic and dilatant cases always display unit-slope lines equivalent to the case as for those of Newtonian fluids. As for the Newtonian behavior, the late-time pressure-derivative decreases in both dilatant or pseudoplastic cases.

Equation 7 is here rewritten based upon reservoir drainage area, so that:

$$
t_{D A}=\frac{t}{G\left(\pi r_{e}^{3-n}\right)}
$$




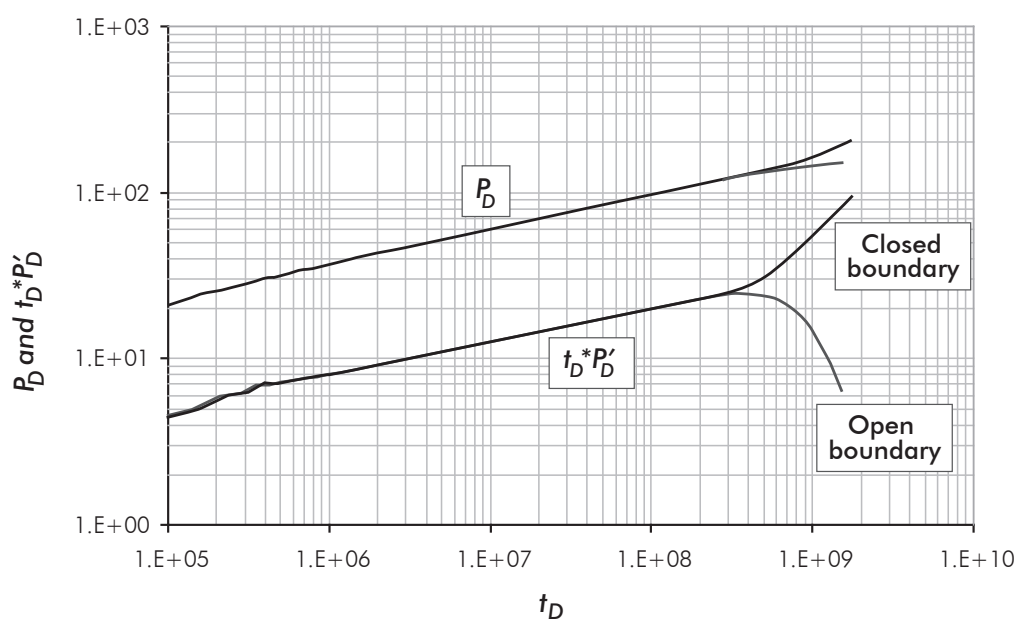

Figure 1. Dimensionless pressure and pressure-derivative behaviors in closed and open boundary systems for a non-Newtonian pseudoplastic fluid with $n=0.5 ; r_{\mathrm{e}}=2000 \mathrm{ft}$.

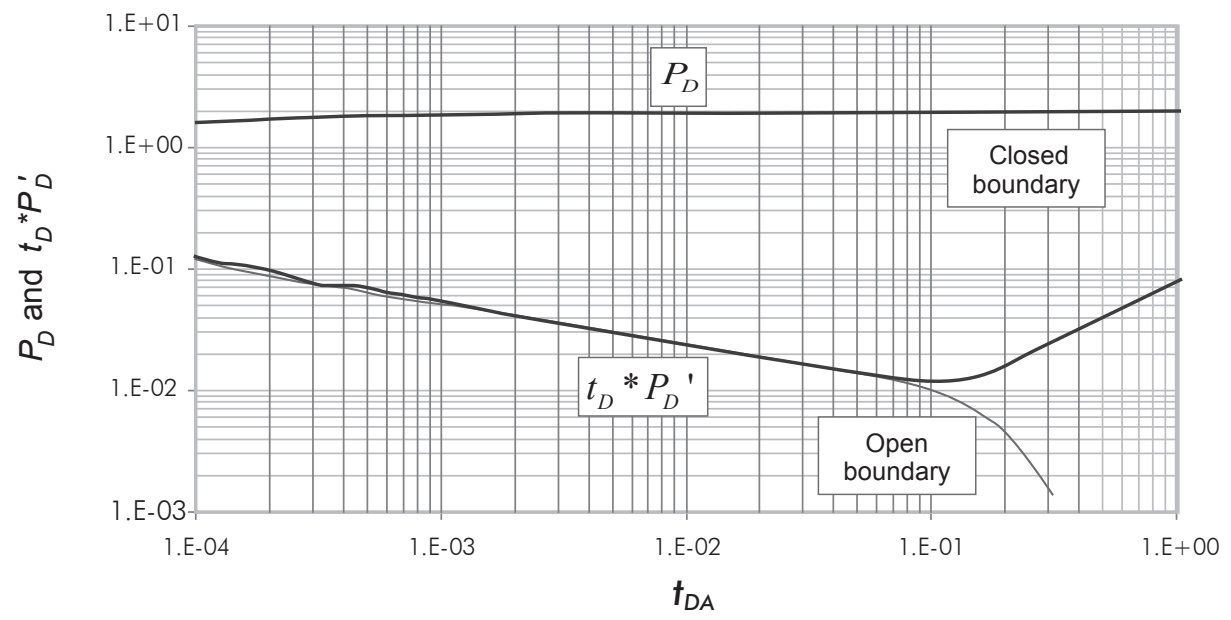

Figure 2. Dimensionless pressure and pressure-derivative behaviors in closed and open boundary systems for a non-Newtonian dilatant fluid with $n=1.5 ; r_{\mathrm{e}}=2000 \mathrm{ft}$.

Remembering that the late-time pressure-derivative expression for closed systems is given by:

$t_{D} * P_{D}^{\prime}=2 \pi t_{D A}$

We propose here a combination of Equations 17, 21 and 22 to develop an analytical expression to find well drainage area,

$A=\pi\left[\frac{t_{r p i N N}}{G}\left(\frac{1}{4}\right)^{1 / \alpha-1}\right]^{2 / 3-n}$
Where $t_{r p i N N}$ is the intersection point formed by the straight-lines of the radial and pseudosteady-state flow regimes exhibited by the derivative response. Equation 23 was multiplied by $\left(p^{(1 / a-1)}\right)^{1 / 3-n}$ as a correction factor. This is valid for both dilatant and pseudoplastic non-Newtonian fluids. This correction factor was empirically included since the solution deviates from its expected value as the absolute value of $n$ increases. There is no pressure-derivative expression for open boundary systems. Then, for pseudoplastic fluids the following correlation is also developed in this work which works for the full range of dilatant fluids which is $1<n<2$, 


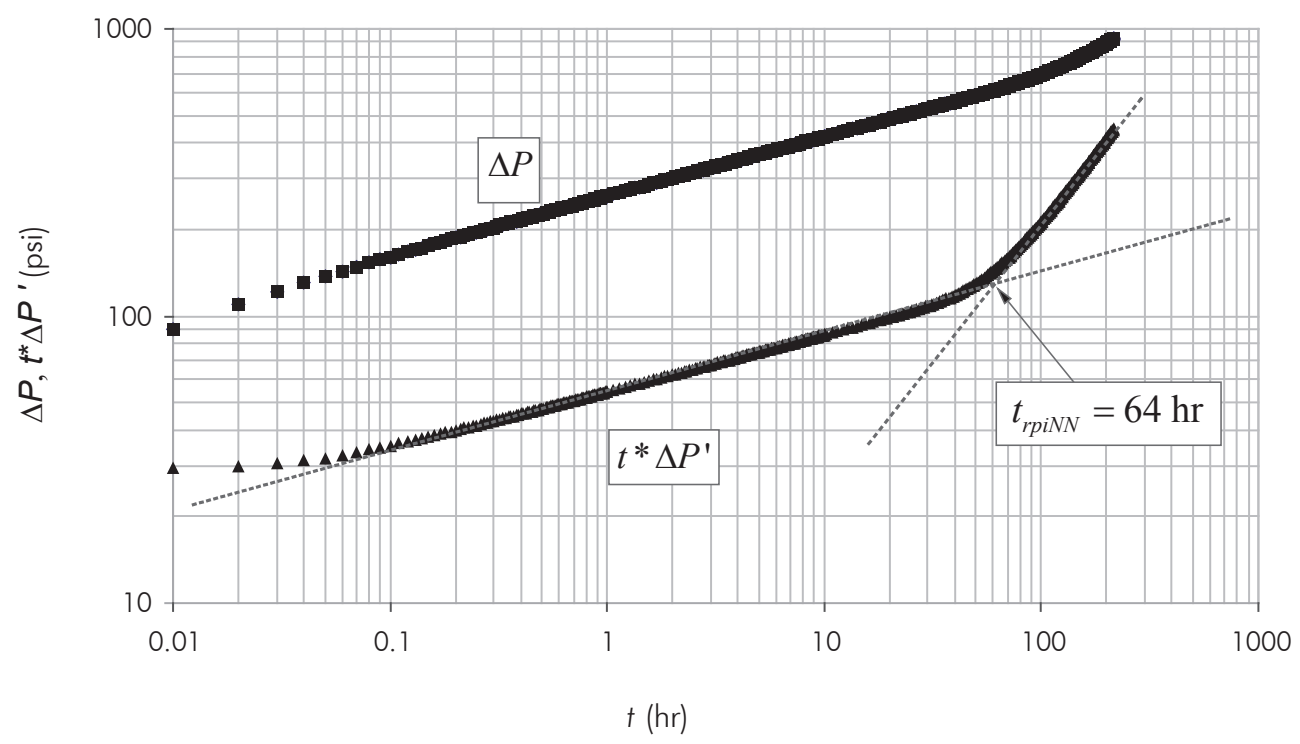

Figure 3. Pressure and pressure derivative for example 1.

$t_{D A_{N N}}=-0.003 n^{2}+0.0337 n+0.052$

$t_{D A N N}$ refers to the dimensionless time based upon area given for non-Newtonian fluids. Equating Equation 24 to 21 and solving for reservoir drainage, it yields,

$A=\pi\left[\frac{t_{r s i N N}}{G \pi\left(-0.003 n^{2}+0.0337 n+0.052\right)}\right]^{2 / 3-n}$

For dilatant fluids the correlation found is:

$t_{D A_{N N}}=0.9175 n^{3}-3.7505 n^{2}+5.1777 n-2.2913$

In a similar fashion as for the pseudoplastic case,

$A=\pi\left[\frac{t_{r i i N N}}{G \pi\left(0.9175 n^{3}-3.7505 n^{2}+5.1777 n-2.2913\right)}\right]^{2 / 3-n}$

$t_{r s i N N}$ in Equations 25 and 27 corresponds is the intersection point formed between the straight-line of the radial and negative unit-slope line drawn tangentially to the steady-state flow regime exhibited by the derivative response.

\section{SYNTHETIC EXAMPLES}

\section{Example 1}

Pressure and pressure derivative data for a pseudoplastic fluid are provided in Figure 3 and other relevant information is given below:

$n=0.5$

$k=350 \mathrm{md}$

$h=16.4 \mathrm{ft}$

$f=5 \%$

$B_{o}=1 \mathrm{rb} / \mathrm{STB}$

$\mu_{\text {eff }}=20 \mathrm{cp}^{*} \mathrm{~s}^{\mathrm{n}-1}$

$c_{t}=0.0000689 \mathrm{psi}^{-1}$

$r_{w}=0.33 \mathrm{ft}$

$H=20 \mathrm{cp}^{*} \mathrm{~s}^{\mathrm{n}-1}$

$r_{e}=2000 \mathrm{ft}$

\section{$\underline{\text { Solution }}$}

From Figure 3, the intercept point, $t_{r p i N N}$, of the radial and pseudosteady-state straight lines is $64 \mathrm{hr}$ which is used in Equation 23 to provide a well drainage area of 289.8 acres. Notice that this reservoir has an external radius of $2000 \mathrm{ft}$ which represents an area of 288.5 acres. This allows obtaining an absolute error of $0.224 \%$.

\section{Example 2}

Pressure and pressure derivative data for a dilatant fluid are provided in Figure 4 and other important data are given in example 1 except that $n=1.5$. 


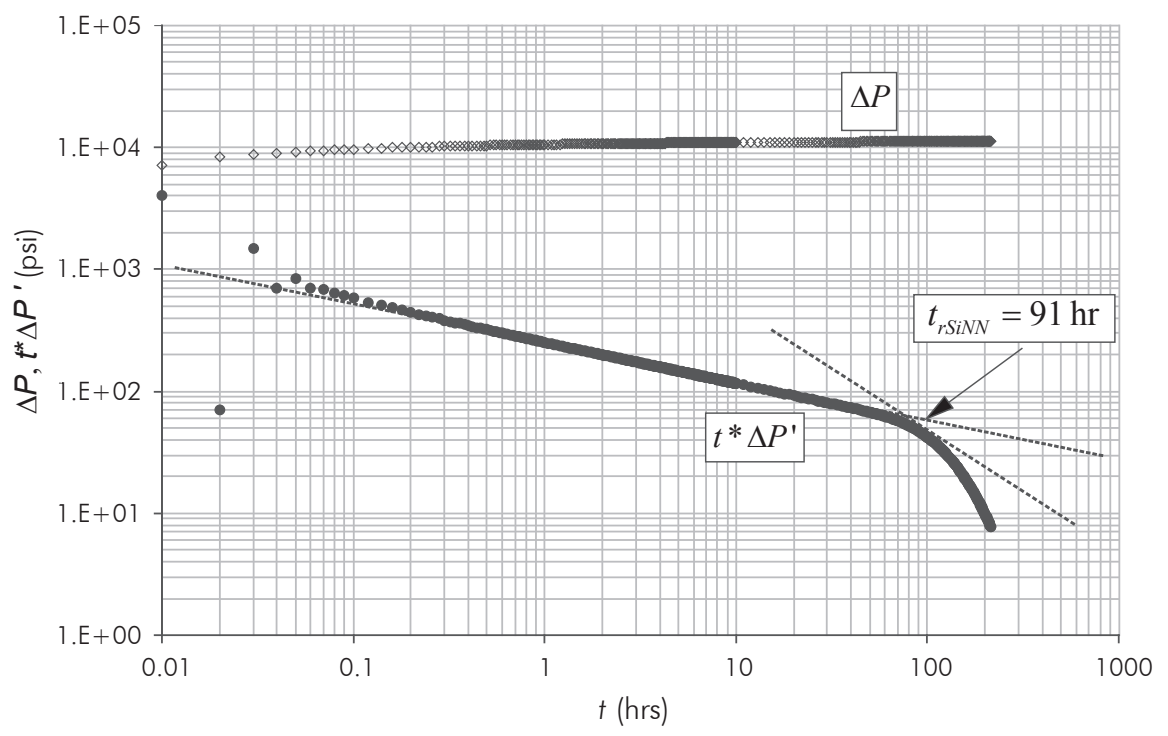

Figure 4. Pressure and pressure derivative for example 2.

\section{$\underline{\text { Solution }}$}

From Figure 4, the intercept point, $t_{r s i N N}$, of the radial and steady-state straight lines is $91 \mathrm{hr}$. This value is used in Equation 27 to provide a well drainage area of 287.22 acres. Notice that as for the former example, the external radius is $2000 \mathrm{ft}$ or an area of 288.5 acres. This allows obtaining an absolute error of $0.219 \%$.

\section{DISCUSSION}

Many examples were used and found to work out well. However, for saving-space reasons, only two were randomically chosen to be included in this study. In all of the examples very low errors in the estimation of the well drainage area were achieved. Actually, for the presented examples the errors are lower than $0.3 \%$ as can be found summarized in Table 1. This is a function of how well the interpreter reads the characteristic points for which purpose computer applications are recommended. It is worthless to compare the results obtained here with the conventional methodology for the Newtonian case. Vongvuthipornchai (1985) has already made comparisons between conventional analysis of Newtonian and Non-Newtonian cases for mobility calculations and found errors. Besides, the error increases as the value of $n$ decreases. Moreover, the determination of drainage area by conventional analysis only works for close systems and fails in constant-pressure reservoir as demonstrated by Escobar, Hernández and Tiab (2010).
This methodology can be applied to either drawdown or buildup tests as proposed by Tiab (1993). However, it has been not tested yet for either injection/fall-off tests for which the application may lose its validity in injection/falloff tests run after injection of non-Newtonian fluids with mobility ratio significantly different from unity.

Table 1. Summary of the results.

\begin{tabular}{|c|c|c|}
\hline Example & Area, Ac & \% Error \\
\hline 1 & 289.8 & 0.224 \\
\hline 2 & 287.22 & 0.219 \\
\hline
\end{tabular}

\section{CONCLUSIONS}

- An estimation of the well drainage area from pressure transient analysis using pressure and pressure derivative log-log plots in reservoirs bearing powerlaw non-Newtonian fluids is presented for the first time. The proposed methodology was successfully tested with synthetic examples since no field data has been yet reported neither in the oil literature nor by operation/services companies. In the worked examples the deviation error is less than $0.3 \%$ compared to simulation input data which indicates a good level of accuracy of the introduced mathematical expressions. 


\section{ACKNOWLEDGMENTS}

The authors gratefully thank Universidad Surcolombiana for providing support to the completion of this work.

\section{REFERENCES}

Escobar, F. H., Hernández, Y. A. \& Tiab, D. (2010). Determination of reservoir drainage area for constant-pressure systems using well test data. CT\&F-Ciencia, Tecnología y Futuro, 4(1), 51-62.

Escobar, F. H., Martínez-Martínez, J. A. \& Montealegre, M. (2010). Pressure and pressure derivative analysis for a well in a radial composite reservoir with a Non-Newtonian/ Newtonian interface. CT\&F-Ciencia, Tecnología y Futuro, 4(2), 33-42.

Gringarten, A. C. (2008). From straight lines to deconvolution: The evolution of the state of the art in well test analysis. SPE Reservoir Evaluation \& Engineering, 11(1), 41-62.

Hirasaki, G. J. \& Pope, G. A. (1974). Analysis of factors influencing mobility and adsorption in the flow of polymer solutions through porous media. SPE Journal. 14(4), 337-346.

Igbokoyi,A. \& Tiab, D. (2007). New type curves for the analysis of pressure transient data dominated by skin and wellbore storage: Non-Newtonian fluid. SPE Production and Operations Symposium. Oklahoma City, U.S.A. SPE 106997.

Ikoku, C. U. (1978). Transient flow of Non-Newtonian Power-Law fluids in porous media. Ph. D. Thesis dissertation, Petroleum Engineering Department, Stanford University, Stanford, U.S.A., 257pp.

Ikoku, C. U. (1979). Practical application of Non-Newtonian transient flow analysis. SPE 64th Annual Technical Conference and Exhibition, Las Vegas, SPE 8351.

Ikoku, C. U. \& Ramey, H. J. Jr. (1979). Transient flow of Non-Newtonian Power-law fluids through in porous media. SPE J., 19(3), 164-174.

Katime-Meindl, I. \& Tiab, D. (2001). Analysis of pressure transient test of non-newtonian fluids in infinite reservoir and in the presence of a single linear boundary by the direct synthesis technique. SPE Annual Technical Conference and Exhibition, New Orleans, U.S.A. SPE 71587.

Martínez, J.A., Escobar, F. H. \& Montealegre, M. (2011). Vertical well pressure and pressure derivative analysis for Bingham fluids in a homogeneous reservoirs. Dyna, 78(166), 21-28.

Odeh, A. S. \& Yang, H. T. (1979). Flow of non-Newtonian powerlaw fluids through in porous media. SPE J., 19(3), 155-163.

Savins, J. G. (1969). Non-Newtonian flow through in porous media. Industrial and Engineering Chemistry, 61(10), $18-47$.

Tiab, D. (1993). Analysis of pressure and pressure derivative without type-curve matching: 1- skin and wellbore storage. J. of Petrol. Science and Eng., 12: 171-181.

Van Poollen, H. K. \& Jargon, J. R. (1969). Steady-state and unsteady-state flow of non-newtonian fluids through porous media. SPE J., 9(1), 80-88.

Vongvuthipornchai, S. (1985). Well test analysis for nonnewtonian fluid flow. Ph. D. Thesis Dissertation, Petroleum Engineering Department, University of Tulsa, Tulsa, U.S.A. 376pp.

Vongvuthipornchai, S. \& Raghavan, R. (1987). Well test analysis of data dominated by storage and skin: nonnewtonian power-law fluids. SPE Formation Evaluation. 2(4), 618-628.

\section{AUTHORS}

\section{Freddy-Humberto Escobar.}

Affiliation: Universidad Surcolombiana.

Ing. Petróleos, Universidad América.

M. Sc., Ph. D. in Petroleum Engineering, University of Oklahoma. e-mail: fescobar@usco.edu.co

\section{Laura-Jimena Vega.}

Affiliation: Universidad Surcolombiana. Ing. Petróleos, Universidad Surcolombiana. e-mail: ljvega@hotmail.com

\section{Luis-Fernando Bonilla.}

Affiliation: Universidad Surcolombiana. Ing. Petróleos, Universidad Surcolombiana.

M. Sc. in Petroleum Engineering, University of Oklahoma.

e-mail: fbonillacamacho@gmail.com 


\begin{tabular}{|rl|}
\hline & \\
& \\
$B$ & NOTATION \\
$c_{t}$ & Total system compressibility, $1 / \mathrm{psi}$ \\
$C$ & Wellbore storage, bbl/psi \\
$C_{f D}$ & Dimensionless fracture conductivity \\
$h$ & Formation thickness, $\mathrm{ft}$ \\
$H$ & Consistency (Power-law parameter), cp* $\mathrm{s}^{\mathrm{n}-1}$ \\
$G$ & Group defined by Equation 4 \\
$G$ & Minimum pressure gradient, psi/ft \\
$G_{D}$ & Dimensionless pressure gradient \\
$k$ & Permeability, md \\
$k$ & Flow consistency parameter \\
$m$ & Slope \\
$n$ & Flow behavior index (power-law parameter) \\
$P$ & Pressure, psi \\
$q$ & Flow/injection rate, STB/D \\
$t$ & Time, hr \\
$r$ & Radius, ft \\
$r_{\mathrm{e}}$ & Reservoir external radius or drainage radius, $\mathrm{ft}$ \\
$t^{*} \Delta P^{\prime}$ & Pressure derivative, psi \\
$t_{\mathrm{D}} * P_{\mathrm{D}}{ }^{\prime}$ & Dimensionless pressure derivative \\
$\tilde{s}$ & Laplace parameter \\
& \\
\hline
\end{tabular}




\begin{tabular}{|rl|}
\hline & \\
$\Delta$ & GREEKS \\
$\phi$ & Phange, drop \\
$\gamma$ & Shear rate, $\mathrm{s}^{-1}$ \\
$\sigma$ & Shear stress, $\mathrm{N} / \mathrm{m}$ \\
$\lambda$ & Dimensionless interposity parameter \\
$\mu$ & Viscosity, cp \\
$\mu_{\text {eff }}$ & Effective viscosity for power-law fluids, $\mathrm{cp}^{*}(\mathrm{~s} / \mathrm{ft})^{\mathrm{n}-1}$ \\
$\tau$ & Shear stress, N/m \\
$\omega$ & Dimensionless storativiy coefficient \\
& \\
& \\
$a p p$ & Apparent \\
$D$ & Dimensionless \\
$D A$ & Dimensionless based on area \\
$D A N N$ & Dimensionless based on area for a non-Newtonian fluid \\
$E$ & External \\
$E f f$ & Effective \\
$I$ & Initial \\
$N$ & Newtonian \\
$N N$ & Non-Newtonian \\
$R$ & Radial (any point on radial flow) \\
$r p i N N$ & Intersect of radial and pseudosteady-state lines \\
$r s i N N$ & Intersect of radial and steady-state lines \\
$W$ & Wellbore \\
& \\
& \\
& \\
\hline
\end{tabular}


